\title{
PENINGKATAN SELF EFFICACY TERHADAP MATEMATIKA DENGAN MENGGUNAKAN MODUL MATEMATIKA KELAS VIII SMP NEGERI 2 BANGKINANG
}

\author{
Irma Fitri \\ Pendidikan Matematika Fakultas Tarbiyah dan Keguruan UIN Sultan Syarif Kasim Riau \\ irmafitri05@yahoo.com
}

\begin{abstract}
This studied to know whether or not there is difference of self efficacy to mathematics. Based on the results of data analysis, it is concluded that there are differences in self efficacy score between students who learn to use mathematics module with students who obtain This study aims to determine the differences in mathematical self efficacy between students who learn to use mathematics module with students who obtain conventional learning. In this research the problem formula is "Is there any difference of self efficacy of student mathematics between students who learn to use math module with students who get conventional learning?". This study is a quasi experimental research, where teachers who play a direct role in the learning process and researchers as an observer. Subjects in this study were students of class VIII SMP Negeri 2 Bangkinang which amounted to 261 people and as a sample class VIII G which amounted to 32 people. While the object of this research is self efficacy against mathematics. The data collected in this study using documentation, observation sheet, test and questionnaire. To know the result of the research is done by using $t$ test conventional learning.
\end{abstract}

Kata kunci: Mathematics Module, Self Efficacy

\begin{abstract}
Abstrak
Penelitian ini bertujuanuntuk mengetahui perbedaan self efficacy matematika antara siswa yang belajar menggunakan modul matematika dengan siswa yang memperoleh pembelajaran konvensional. Dalam penelitian ini rumusan masalahnya adalah "Apakah terdapat perbedaan self efficacy matematika siswa antara siswa yang belajar menggunakan modul matematikadengan siswa yang memperoleh pembelajaran konvensional?". Penelitian ini merupakan penelitian kuasi eksperimen, dimana guru yang berperan langsung dalam proses pembelajaran dan peneliti sebagai observer. Subjek dalam penelitian ini adalah siswa kelas VIII SMP Negeri 2 Bangkinang yang berjumlah 261 orang dan sebagai sampel kelas VIII G yang berjumlah 32 orang. Sedangkan objek penelitian ini adalah self efficacy terhadap matematika.Pengambilan data dalam penelitian ini menggunakan dokumentasi, lembar observasi, tes dan angket. Untuk mengetahui hasil penelitian tersebut dilakukan dengan menggunakan uji $t$ untuk mengetahui ada atau tidaknya perbedaan self efficacy terhadap matematika. Berdasarkan hasil analisis data tersebut, diambil kesimpulan bahwa terdapat perbedaan skor self efficacy antara siswa yang belajar menggunakan modul matematika dengan siswa yang memperoleh pembelajaran konvensional.
\end{abstract}

Kata kunci: Modul Matematika, Self Efficacy

Belajar merupakan suatu aktivitas yang selalu dilakukan sepanjang hayat manusia, bahkan tiada hari tanpa belajar. Belajar dilakukan seseorang untuk mendapatkan perubahan di dalam dirinya melalui pelatihan-pelatihan atau pengalaman-pengalaman.Belajar dapat membawa perubahan bagi pelaku, baik perubahan pengetahuan, sikap, maupun keterampilan. Dengan perubahan-perubahan tersebut, tentunya pelaku akan terbantu dalam memecahkan permasalahan hidup dan bisa menyesuaikan dengan lingkungannya. Belajar tidak hanya mampu untuk mengetahui, tapi mampu untuk memahami, terutama pelajaran yang bersifat eksak dan merupakan ilmu dasar untuk pelajaran lainnya, seperti matematika. Matematika merupakan salah satu ilmu dasar yang mempunyai peranan penting dalam penguasaan ilmu pengetahuan dan teknologi, baik aspek 
penerapannya maupun aspek penalarannya. Menuurut Herman Hudoyo kemampuan siswa menguasai ilmu pengetahuan dan teknologi didasari atas penguasaan matematika.

Tujuan pembelajaran matematika adalah agara siswa mampu memahami konsep, merancang model, menyelesaikan model sehingga mampu memecahkan masalah. Sebagaiamana tujuan pembelajaran matematika dalam peraturan Menteri Pendidikan Nasional RI Nomor 22 tahun 2006, dijelaskan bahwa tujuan pembelajaran matematika di sekolah adalah agar siswa memiliki kemampuan memahami konsep matematika, menjelaskan keterkaitan antar konsep dan mengaplikasikan konsep atau algoritma secara luwes, akurat, efisien, dan tepat dalam pemecahan masalah. Siswa mampu menggunakan penalaran pada pola dan sifat, melakukan manipulasi matematika dalam membuat generalisasi, menyusun atau menjelaskan gagasan dan pernyataan matematika. Siswa mampu memecahkan masalah yang meliputi kemampuan memahami masalah, merancang model matematika, menyelesaikan model dan menafsirkan solusi yang diperoleh. Siswa mampu mengomunikasikan gagasan dengan simbol, tabel, diagram atau media lain untuk memperjelas keadaan atau masalah. Siswa memiliki sikap menghargai kegunaan matematika dalam kehidupan yaitu memiliki perasaan ingin tahu, memiliki perhatian dan minat dalam mempelajari matematika, serta sikap ulet dan percaya diri dalam pemecahan masalah.

Berdasarkan tujuan pembelajaran tersebut, dijelaskan bahwa siswa harus memiliki kemampuan kognitif dan afektif. Salah satu kemampuan afektif yang dimiliki adalah rasa percaya diri. Rasa percaya diri identik dengan self efficacy. Jadi self efficacy sangat penting dimiliki oleh siswa. Berdasarkan wawancara dengan guru mata pelajaran matematika di SMP Negeri 2 Bangkinang, self efficacy terhadap matematika masih tergolong rendah. Guru telah berusaha menguranginya dengan cara memberikan soal yang berbeda pada siswa, akan tetapi usaha guru tersebut belum dapat meningkatkan self efficacy siswa. Hal ini dapat terlihat dari masih banyak siswa yang mengerjakan PR di sekolah dan menyontek PR teman.Banyak siswa yang menyontek kepada temannya yang dianggap lebih pintar ketika ujian. Siswa lebih meyakini jawaban yang dikerjakan oleh temannya.

Salah satu cara untuk mengatasi permasalahan tersebut adalah dengan menggunakan modul matematika. Modul merupakan seperangkat bahan ajar yang disajikan secara sistematis dan penggunaanya dapat belajar dengan atau tanpa guru sehingga siswa bisa mandiri dan meningkatkan percaya diri. Menurut Ari Purbayanto modul disusun dengan bahasa yang mudah dipahami oleh siswa sesuai dengan pengetahuan dan usia siswa agar siswa dapat belajar mandiri dan dapat mengukur tingkat pemahaman peserta didik. Siswa yang mandiri dapat meningkatkan percaya diri. Setelah pembelajaran berakhir, akan dilakukan penyebaran angket untuk melihat pengaruh yang ditimbulkan terhadap self efficacy setelah menggunakan modul matematika.

Sesuai dengan masalah yang telah dikemukakan di atas, maka tujuan penelitian ini adalah untuk mengetahui perbedaan self efficacy terhadap matematika antara siswa yang belajar menggunakan modul matematika dengan siswa yang memperoleh pembelajaran konvensional. 


\section{METODE}

Subjek dalam penelitian ini adalah siswa kelas VIII SMP Negeri 2 Bangkinang. Sedangkan objek dalam penelitian ini adalah self efficacy terhadap matematika siswa.Pengambilan sampel diambil dengan menggunakan teknik sampel pertimbangan yaitu kelas VIII G dengan jumlah siswa 32 orang dari seluruh kelas VIII SMP N 2 Bangkinang.

Teknik yang digunakan dalam penelitian ini adalah dokumentasi yang digunakan untuk mengetahui sejarah sekolah, keadaan guru, dan siswa serta sarana prasarana yang ada di sekolah.Metode observasi menggunakan lembar pengamatan siswa untuk mengamati kegiatan guru dan siswa yang diharapkan muncul dalam pembelajaran matematika dengan modul matematika. Angket digunakan untuk melihat perkembangan self efficacy siswa.Teknik analisis data yang digunakan pada penelitian ini adalah uji t.

\section{HASIL DAN PEMBAHASAN}

Self Efficacy yang dimaksud adalah keyakinan seorang siswa dengan kemampuannya dalam pembelajaran matematika. Menurut Dale Schunk "self efficacy mempengaruhi siswa dalam memilih kegiatannya. Siswa dengan self efficacy yang rendah mungkin menghindari pelajaran yang banyak tugasnya, khususnya untuk tugas-tugas yang menantang, sedangkan siswa dengan self efficacy yang tinggi mempunyai keinginan yang besar untuk mengerjakan tugas-tugasnya." (Aisyah, 2008: 10).

Siswa yang mempunyai self efficacy yang tinggi merupakan siswa yang mempunyai keyakinan, ketegasan, dan bersedia mengambil resiko dalam proses pembelajaran demi tercapainya tujuan pembelajaran. Mereka yakin dalam mengerjakan tugas yang dianggap lebih sulit dan yakin dengan hasil pekerjaannya. Berbeda dengan siswa yang memiliki self efficacy rendah, mereka takut untuk mengerjakan tugas karena tidak yakin dengan hasil pekerjaannya sehingga menimbulkan keinginan untuk menyontek pekerjaan temannya.

Dalam self efficacy terdapat empat prinsip, yaitu :

1. Self efficacy dapat meningkatkan prestasi pribadi

2. Self efficacy dapat meningkat atau menurun jika melihat orang lain yang memiliki keberhasilan atau kegagalan yang sama pada suatu tugas tertentu.

3. Self efficacy dapat timbul jika seseorang diberi sugesti mampu untuk mengerjakan suatu tugas, tapi jika gagal self efficacy tersebut akan hilang.

4. Self efficacy memiliki hubungan dengan tekanan emosional (Aisyah, 2008: 10).

Persepsi self efficacy menurut Bandura dalam Risnasonansi dapat dibentuk dengan menginterpretasi informasi dari empat sumber, yaitu :

1. Pengalaman otentik (authentic mastery experience), yang merupakan sumber yang paling berpengaruh, karena kegagalan/keberhasilan pengalaman yang serupa kelak. Khususnya kegagalan yang terjadi pada awal tindakan tidak dapat dikaitkan dengan kurangnya upaya atau pengaruh lingkungan eksternal.

2. Pengalaman orang lain (vicarious experience), yang dengan memperhatikan keberhasilan/kegagalan orang lain, seseorang dapat mengumpulkan informasi yang 
diperlukan untuk membuat pertimbangan tentang kemampuan dirinya sendiri. Model pengalaman orang lain ini sangat berpengaruh apabila ia mendapat situasi yang serupa dan miskin pengalaman dalam pengalaman tersebut.

3. Pendekatan sosial atau verbal, yaitu pendekatan yang dilakukan dengan meyakini seseorang bahwa ia memliki kemampuan untuk melakukan sesuatu. Perlu diperhatikan, bahwa pernyataan negatif tentang kompetensi seseorang dalam area tertentu sangat berakibat buruk terhadap mereka yang sudah kehilangan kepercayaan diri, misalnya pernyataan bahwa kaum perempuan tidak sesuai untuk belajar matematika, akan mengakibatkan kaum perempuan akan percaya bahwa mereka tidak kompeten dalam matematika.

4. Indeks, psikologis, dimana status fisik dan emosi akan mempengaruhi kemampuan seseorang. Emosi yang tinggi, seperti kecemasan akan matematika, akan merubah kepercayaan diri seseorang tentang kemampuannya. Seseorang dalam keadaan stress, depresi, atau tegang dapat menjadi indikator kecenderungan akan terjadinya kegagalan. (Risnasonansi: 66)

\section{Tabel 1}

INDIKATOR SELF EFFICACY

\begin{tabular}{|l|l|}
\multicolumn{1}{|c|}{$\begin{array}{c}\text { Sumber/Aspek Self Efficacy } \\
\text { (Source of Self-Efficacy) }\end{array}$} & \multicolumn{1}{|c|}{ Deskripsi } \\
\hline $\begin{array}{l}\text { Pengalaman kinerja (Performance } \\
\text { Experience) }\end{array}$ & $\begin{array}{l}\text { Indikator yang didasarkan kinerja pada } \\
\text { penilaian/pengalaman sebelumnya. (An indikator od } \\
\text { capability based on performance in past assessment, } \\
\text { course, etc) }\end{array}$ \\
\hline $\begin{array}{l}\text { Pengalaman orang lain (Vicarious } \\
\text { Experience) }\end{array}$ & $\begin{array}{l}\text { Bukti yang didasarkan pada kompetensi dan } \\
\text { perbandingan informatif dengan hasil yang dicapai } \\
\text { orang lain. (A source of evidence based on } \\
\text { competencies and informative comparison with the } \\
\text { attainmentof others) }\end{array}$ \\
\hline $\begin{array}{l}\text { Aspek dukungan langsung/sosial } \\
\text { (Verbal Persuasion) }\end{array}$ & $\begin{array}{l}\text { Mengacu pada umpan balik langsung/kata-kata dari } \\
\text { guru atau orang lain yang lebih dewasa. (this refers to } \\
\text { verbal feedback from teacher or adults) }\end{array}$ \\
\hline $\begin{array}{l}\text { Aspek psikologis dan afektif } \\
\text { (Physiologikal and Affective States) }\end{array}$ & $\begin{array}{l}\text { Penilaian kemampuan, kekuatan dan kelemahan. } \\
\text { (Judgement of capability, strenght, and vulnerability to } \\
\text { dydfunsition) }\end{array}$ \\
\hline
\end{tabular}

Sumber : Risnasonansi: Peningkatan Kemampuan Berpikir Kreatif dan Self Efficacy Matematika Siswa melalui Pembelajaran Inkuiri

Berdasarkan prinsip dan indikator, self efficacy bisa ditingkatkan melalui kinerja dan pengalaman siswa.Sementara, modul merupakan sebuah buku yang ditulis secara sistematis dan menggunakan bahasa yang mudah dipahami dengan tujuan agar siswa dapat belajar secara mandiri. 
Hal senada juga dikemukakan oleh Badan Pengembangan Pendidikan Departemen Pendidikan dan Kebudayaan, bahwa yang dimaksud modul adalah suatu unit program kegiatan belajar mengajar terkecil yang secara terperinci menggariskan hal-hal sebagai berikut:

1. Tujuan-tujuan instruksional umum yang akan ditunjang pencapaiannya

2. Topik yang akan dijadikan pangkal proses belajar mengajar

3. Tujuan-tujuan instruksional khusus yang akan dicapai oleh siswa

4. Pokok-pokok materi yang akan dipelajari dan diajarkan

5. Kedudukan dan fungsi satuan (modul) dalam kesatuan program yang lebih luas

6. Peranan guru di dalam proses belajar mengajar

7. Alat-alat dan sumber yang akan dipakai

8. Kegiatan-kegiatan belajar yang harus dilakukan dan dihayati siswa secara berurutan

9. Lembaran-lembaran kerja yang harus diisi siswa

10. Program evaluasi yang akan dilaksanakan selama berjalannya proses belajar ini. (St. Vembrianto)

Sementara itu menurut Surahman, modul adalah satuan program pembelajaran terkecil yang dapat dipelajari oleh siswa secara perseorangan (self instructional) (Andi Prastowo). Berdasarkan beberapa pendapat tersebut dapat dipahami bahwa modul adalah sebuah bahan ajar yang disusun secara sistematis dengan bahasa yang mudah dipahamai oleh siswa sesuai tingkat pengetahuan dan usia siswa agar mereka dapat belajar secara mandiri dengan bantuan yang minimal dari guru. Kemudian dengan modul siswa dapat mengukur tingkat pemahamannya sendiri sehingga apabila telah memahami maka siswa dapat lanjut pada modul berikutnya.

Sebagai salah satu bentuk bahan ajar modul memiliki fungsi sebagai berikut:

1. Bahan ajar mandiri. Penggunaan modul dalam proses pembelajaran berfungsi meningkatkan kemampuan peserta didik untuk belajar sendiri tanpa tergantung kepada siswa

2. Pengganti fungsi guru. Modul sebagai bahan ajar mampu menjelaskan materi dengan baik dan mudah dipahami oleh siswa sehingga bisa menjadi pengganti guru dalam menjelaskan materi.

3. Sebagai alat evaluasi. Modul menuntut siswa agar dapat mngukur kemampuannya sendiri terhadap materi yang dipelajari.

4. Modul sebagai bahan rujukan bagi siswa. Modul memuat berbagai materi yang harus dipelajari oleh siswa maka modul juga berfungsi sebagai bahan rujukan bagi siswa.

Menurut Anwar karakteristik modul pembelajaran sebagai berikut :

1. Self instructional. Siswa mampu membelajarkan diri sendiri, tidak tergantung pada pihak lain.

2. Self contained. Seluruh materi pembelajaran dari satu unit kompetensi yang dipelajari terdapat didalam satu modul utuh.

3. Stand alone. Modul yang dikembangkan tidak tergantung pada media lain atau tidak harus digunakan bersama-sama dengan media lain.

4. Adaptif. Modul hendaknya memiliki daya adaptif yang tinggi terhadap perkembangan ilmu dan teknologi. 
5. User friendly. Modul hendaknya juga memenuhi kaidah akrab bersahabat/akrab dengan pemakainya.

6. Konsistensi. Konsisten dalam penggunaan font, spasi, dan tata letak.

Menurut Wijaya ciri-ciri pengajaran modul pembelajaran adalah :

1. Siswa dapat belajar individual, ia belajar dengan aktif tanpa bantuan maksimal dari guru.

2. Tujuan pelajaran dirumuskan secara khusus. Rumusan tujuan bersumber pada perubahan tingkah laku.

3. Tujuan dirumuskan secara khusus sehingga perubahan tingkah laku yang terjadi pada diri siswa segera dapat diketahui. Perubahan tingkah laku diharapkan sampai $75 \%$ penguasaan tuntas (mastery learning).

4. Membuka kesempatan kepada siswa untuk maju berkelanjutan menurut kemampuannya masingmasing.

5. Modul merupakan paket pengajaran yang bersifat self-instruction, dengan belajar seperti ini, modul membuka kesempatan kepada siswa untuk mengembangkan dirinya secara optimal.

6. Modul memiliki daya informasi yang cukup kuat. Unsur asosiasi, struktur, dan urutan bahan pelajaran terbentuk sedemikian rupa sehingga siswa secara spontan mempelajarinya.

7. Modul banyak memberikan kesempatan kepada siswa untuk berbuat aktif.

Berdasarkan ciri dan karakteristik modul pembelajaran tersebut dapat dipahami bahwa modul pembelajaran disusun agar siswa dapat belajarn secara individual dan membuka kesempatan siswa untuk mengembangkan dirinya sehingga terbentuk sikap aktif, mandiri dan percaya diri. Dengan demikian akan meningkatkan self efficacy pada siswa.

Tjipto mengungkapkan beberapa keuntungan yang diperoleh jika belajar menggunakan modul, antara lain :

1. Motivasi siswa dipertinggi karena setiap kali siswa mengerjakan tugas pelajaran dibatasi dengan jelas dan yang sesuai dengan kemampuannya.

2. Sesudah pelajaran selesai guru dan siswa mengetahui benar siswa yang berhasil dengan baik dan mana yang kurang berhasil.

3. Siswa mencapai hasil yang sesuai dengan kemampuannya.

4. Beban belajar terbagi lebih merata sepanjang semester.

5. Pendidikan lebih berdaya guna.

Selain itu Santyasa dalam Suryaningsih juga menyebutkan beberapa keuntungan yang diperoleh dari pembelajaran dengan penerapan modul adalah sebagai berikut :

1. Meningkatkan motivasi siswa, karena setiap kali mengerjakan tugas pelajaran yang dibatasi dengan jelas dan sesuai dengan kemampuan.

2. Setelah dilakukan evaluasi, guru dan siswa mengetahui benar, pada modul yang mana siswa telah berhasil dan pada bagian modul yang mana mereka belum berhasil.

3. Bahan pelajaran terbagi lebih merata dalam satu semester. 
4. Pendidikan lebih berdaya guna, karena bahan pelajaran disusun menurut jenjang akademik.

Dengan demikian, modul dalam proses belajar mengajar mempunyai kelebihan dalam hal menigkatkan motivasi dan kemandirian siswa yang juga berpengaruh pada self efficacy siswa. Akan tetapi proses pembelajaran juga mempunyai kelemahan, antara lain

1. Biaya pengembangan bahan tinggi dan waktu yang dibutuhkan lama.

2. Menentukan disiplin belajar yang tinggi yang mungkin kurang dimiliki oleh siswa pada umumnya dan siswa yang belum matang pada khususnya.

3. Membutuhkan ketekunan yang lebih tinggi dari fasilitator untuk terus menerus mamantau proses belajar siswa, memberi motivasi dan konsultasi secara individu setiap waktu siswa membutuhkan.

Menurut Andriani, kegunaan modul dalam proses pembelajaran antara lain sebagai penyedia informasi dasar karena dalam modul disajikan berbagai materi pokok yang masih bisa dikembangkan lebih lanjut, sebagai bahan instruksi atau bahan petunjuk bagi siswa, serta sebagai bahan pelengkap dengan ilustrasi dan foto yang komunikatif (Belawati). Jadi modul berguna untuk menjadi petunjuk mengajar yang efektif bagi guru serta menjadi bahan berlatih bagi siswa dalam melakukan penilaian sendiri (self assesment) dan dalam meningkatkan self efficacy.

Self efficacy dianalisis melalui data hasil angket skala keyakinan diri siswa sebelum menggunakan modul (angket awal) dan angket skala keyakinan siswa setelah menggunakan modul (angket akhir). Namun, sebelumnya data tersebut diujikan untuk mengetahui homogen dan normal data yang kemudian dilanjutkan dengan analisis data untuk mengetahui adanya self efficacy terhadap matematika siswa dengan menggunakan modul. Pada bagian ini akan dibahas mengenai kemampuan awal, kemampuan akhir dan perbedaan self efficacyterhadap matematika siswadengan menggunakan modul.

1. Kemampuan Awal

a. Hasil Uji Homogenitas

Pengujian homogenitas yang peneliti lakukan adalah dari hasil angket sebelum proses belajar mengajar menggubakan modul. Selanjutnya, dilakukan uji homogenitas varians terhadap data tersebut untuk dua kelas yakni kelas eksperimen dan kelas kontrol. Hasil rangkuman disajikan sebagai berikut:

TABEL 2

NILAI VARIAN BESAR DAN KECILKELOMPOK TINGGI (KELAS EKSPERIMEN DAN KELAS KONTROL)

\begin{tabular}{|c|c|c|}
\hline Nilai Varian Sampel & Kelas VIII G & Kelas VIII H \\
\hline $\mathrm{S}^{2}$ & 52,57 & 60,7 \\
\hline $\mathrm{N}$ & 6 & 11 \\
\hline
\end{tabular}

Menghitung varians terbesar dan terkecil:

$\mathrm{F}_{\text {hitung }}=\frac{\text { varians terbesar }}{\text { varians terkecil }}=\frac{60,7}{52,57}=1,15$

Bandingkan nilai $\mathrm{F}_{\text {hitung }}$ dengan nilai $\mathrm{F}_{\text {tabel }}$ 
Dengan rumus: $\mathrm{db}_{\text {pembilang }}=\mathrm{n}-1=11-1=10$ (untuk varians terbesar)

$\mathrm{db}_{\text {penyebut }}=\mathrm{n}-1=6-1=5$ (untuk varians terkecil)

Taraf signifikan $(\alpha)=0,05$, maka diperoleh $\mathrm{F}_{\text {tabel }}=4,74$

Kriteria pengujian:

Jika : $F_{\text {hitung }}>F_{\text {tabel, }}$, maka tidak homogen

Jika : $F_{\text {hitung }}<F_{\text {tabel, }}$, maka homogen

Ternyata $\mathrm{F}_{\text {hitung }}<\mathrm{F}_{\text {tabel }}$ atau $1,15<4,74$, maka varians-varians adalah homogen.

b. Hasil Uji Normalitas

Selanjutnya skor angket awal diolah dengan uji liliefors untuk menguji normalitas. Hasil pengujian normalitas bagi skor angket untuk kelas kontrol dan kelas eksperimen juga dibedakan berdasarkan kelompok, yaitu :

TABEL 3

UJI NORMALITAS

\begin{tabular}{|l|l|l|l|}
\hline \multicolumn{1}{|c|}{ Kelas } & \multicolumn{1}{c|}{ L Hitung } & \multicolumn{1}{c|}{ L Tabel } & \multicolumn{1}{c|}{ Kriteria } \\
\hline Eksperimen & 0,2422 & 0,319 & Normal \\
\hline Kontrol & 0,1124 & 0,249 & Normal \\
\hline
\end{tabular}

2. Kemampuan Akhir

a. Hasil Uji Normalitas

Kemampuan akhir siswa dilihat berdasarkan skor angket dari kedua kelas penelitian yaitu kelas eksperimen yang mengikuti proses belajar mengajar dengan menggunakan modul dan kelompok kontrol yang mengikuti pembelajaran konvensional. Selanjutnya skor angket akhir diolah dengan menggunakan uji liliefors untuk menguji normalitas.

Hasil pengujian normalitas bagi skor angket untuk kelas kontrol dan kelas eksperimen dibedakan berdasarkan kelompok, selengkapnya dapat dilihat sebagai berikut:

TABEL 4

UJI NORMALITAS

\begin{tabular}{|l|l|l|l|}
\hline \multicolumn{1}{|c|}{ Kelas } & \multicolumn{1}{c|}{ L Hitung } & \multicolumn{1}{c|}{ L Tabel } & \multicolumn{1}{c|}{ Kriteria } \\
\hline Eksperimen & 0,192 & 0,258 & Normal \\
\hline Kontrol & 0,1763 & 0,337 & Normal \\
\hline
\end{tabular}

Karena telah memenuhisyarat tersebut, kemudian dilanjutkan analisis data dengan uji T. Pengambilan keputusandilakukan dengan cara membandingkan nilai $t_{\text {hitung }}$ dengan $t_{\text {tabel, }}$, dengan ketentuan sebagai berikut:

Jika $\mathrm{t}_{\text {hitung }}<\mathrm{t}_{\text {tabel }}$, maka $\mathrm{H}_{0}$ diterima dan $\mathrm{H}_{\mathrm{a}}$ ditolak. 
Jika $t_{\text {hitung }}>\mathrm{t}_{\text {tabel }}$, maka $\mathrm{H}_{0}$ ditolak dan $\mathrm{H}_{\mathrm{a}}$ diterima.

Nilai $t_{\text {hitung }}=3,57$ berarti bahwa $t_{\text {hitung }}$ lebih besar $t_{\text {tabel }}$ pada taraf signifikan $5 \%$ maupun taraf signifikan $1 \%$ dengan $\mathrm{df}=15$. Dengan df diperoleh dari $\mathrm{t}_{\text {tabel }}$ pada taraf signifikan 5\% dan $1 \%$ sebesar 2,13 dan 2,95. Ini berarti $t_{\text {hitung }}>t_{\text {tabel }}$, maka diputuskan bahwa $\mathrm{H}_{0}$ ditolak dan $\mathrm{H}_{\mathrm{a}}$ diterima. Dengan demikian dapat disimpulkan bahwa terdapat perbedaan self efficacy siswa yang belajar menggunakan modul dengan siswa yang memperoleh pembelajaran konvensional.

Peningkatan yang signifikan pada kelas eksperimen dikarenakan dalam pembelajaran di kelas menggunakan modul matematika. Modul matematika merupakan bahan ajar yang sistematis, menggunakan bahasa yang mudah dipahami dan dapat meningkatkan kemandirian siswa.

Pada pertemuan pertama, pembelajaran dengan menggunakan modul belum berjalan dengan lancar, karena masih banyak siswa yang belum terbiasa belajar mandiri dengan minimnya peran guru.. Pertemuan kedua dan ketiga siswa sudah mulai biasa menggunakan modul dan guru sudah bisa sedikit mengurangi untuk menjelaskan materi. Pertemuan keempat, proses pembelajaran dengan menggunakan modul sudah berjalan dengan lancar dimana siswa sudah terbiasa belajar mandiri. Pada pertemuan kelima proses pembelajaran dengan menggunakan modul lebih disempurnakan lagi dengan semua siswa sudah mulai terbiasa belajar mandiri dan bisa mengukur kemampuan pemngetahuannya masing-masing.

Berdasarkan $t_{0}$ tentang self efficacy siswa pada pokok bahasan Sistem Persamaan Linear Dua Variabel menunjukkan bahwa meanself efficacykelas yang menggunakanmodul matematika lebih tinggi daripadamean kelas yang memperoleh pembelajaran konvensional. Hal ini menunjukkan bahwa penggunaan modul matematika dalam pembelajaran matematika memiliki perbedaan yang signifikan di mana self efficacy kelas eksperimen lebih tinggi dari kelas kontrol.

\section{KESIMPULAN DAN SARAN}

Berdasarkan hasil penelitian, dapat diambil kesimpulan bahwa terdapat perbedaan skor self efficacy antara siswa yang belajar menggunakan modul matematika dengan siswa yang memperoleh pembelajaran konvensional dengan nilai $t_{\text {hitung }}=8,25$ lebih besar dari $t_{\text {tabel }}$ pada taraf signifikan $5 \%$ maupun taraf signifikan $1 \%$ sebesar 2,13 dan 2,95.

\section{DAFTAR PUSTAKA}

Aisyah. (2008). Pengaruh Self Efficacy, Kecerdasan Emosional, Keinovatifan, Komitmen Organisasi Terhadap Kinerja Pejabat Eselon III Pemda Kota Palembang. UNJ. Jakarta.

Anwar, Ilham. (2010). Pengembangan Bahan Ajar. Bahan Kuliah Online. Direktori UPI. Bandung.

Belawati. (2003). Pengembangan Bahan Ajar. Jakarta: Pusat Penerbitan Universitas Terbuka. 
Hudoyo, Herman. (1990). Pengembangan Kurikulum Matematika dan Pelaksanaannya Di Depan Kelas. Surabaya: Usaha Nasional.

Nurdin, Syafrudin. (2005). Model Pembelajaran yang Memperhatikan Keragaman Individu Siswa dalam Kurikulum Berbasis Kompetensi.Ciputat: Quantum Teaching.

Risnawati. (2008). Strategi Pembelajaran Matematika. Pekanbaru: Suska Press.

Risnasonansi. Peningkatan Kemampuan Berpikir Kreatif dan Self Efficacy Matematika Siswa melalui Pembelajaran Inkuiri. Disertasi tidak diterbitkan.

St. Vembrianto. (1985). Pengantar Pengajaran Modul. Yogyakarta: Yayasan Pendidikan Paramita.

Suryaningsih, Nunik Setiyo. (2010). Pengembangan media cetak modul sebagai media pembelajaran mandiri pada mata pelajaran teknologi Informasi dan Komunikasi kelas VII semester 1 di SMPN 4 Jombang. Surabaya: Skripsi yang tidak dipublikasikan.

Utomo, Tjipto. (1991). Peningkatan dan Pengembangan Pendidikan. Jakarta: Gramedia Pustaka Utama.

Wijaya, Cece,.dkk. (1988). Upaya Pembaharuan Dalam Pendidikan dan Pengajaran. Bandung: Remadja Karya. 